\title{
FEATURE Little River Drainage District conversion of Big Swamp to fertile agricultural land
}

\author{
Kenneth R. Olson, Lois Wright Morton, and David Speidel
}

M ore than a century ago, American swamps and river lowlands were considered wasteland of no value and a hindrance to land development. The Swamp Land Acts of 1849, 1850, and 1860 granted states the right to reclaim 26 million ha $(64.9$ million ac) of swamps through the construction of levees and open channels (ditches) to control flooding; to encourage settlement, land cultivation, and commerce; and to eliminate widespread mosquito breeding (USGS 2014). Southeast Missouri, once one of the world's largest tracts of forested bottomlands, was a vast wilderness of bald cypress (Taxodium distichum L.), tupelo (gum; Nyssa L.), hardwoods, and water (figure 1), barely accessible to settlers migrating west. In the early 1890s, these historic river floodplains and their tributaries were drained and transformed into fertile agricultural lands in an ambitious engineering feat comparable to the construction of the Panama Canal (Pracht and Banks 2002; Pierce et al. 2012).

Today this vast network of ditches (figure 2), channels, and levees in southeast Missouri bottomlands makes possible an intensive system of agriculture, which produces almost a third of Missouri's agricultural economic output and has changed the hydrology, nutrient cycling, biodiversity, and structure of the entire ecosystem (Pierce et al. 2012). Unified and managed by the Little River Drainage District (LRDD; figure 3) with support from the US Army Corps of Engineers (USACE) (Camillo 2012), this region drains 208,000 ha $(520,000 \mathrm{ac})$ of bottomlands and is the drainage outlet for the runoff from 480,000 ha $(1.2$ million ac) of bottomlands and uplands to the Mississippi River at Helena,

Kenneth R. Olson is professor of soil science in the College of Agricultural, Consumer, and Environmental Sciences, University of Illinois, Urbana, Illinois. Lois Wright Morton is professor of sociology in the College of Agriculture and Life Sciences, lowa State University, Ames, lowa. David Speidel is a Soil and Water Conservation Society member, Benton, Missouri.

\section{Figure 1}

The Mingo National Wildlife Refuge, a 8,670 ha bottomland preserve, is a small restored remnant of the original 480,000 ha Missouri swamp that was transformed into fertile agricultural lands by extensive drainage systems in the early $1900 \mathrm{~s}$.

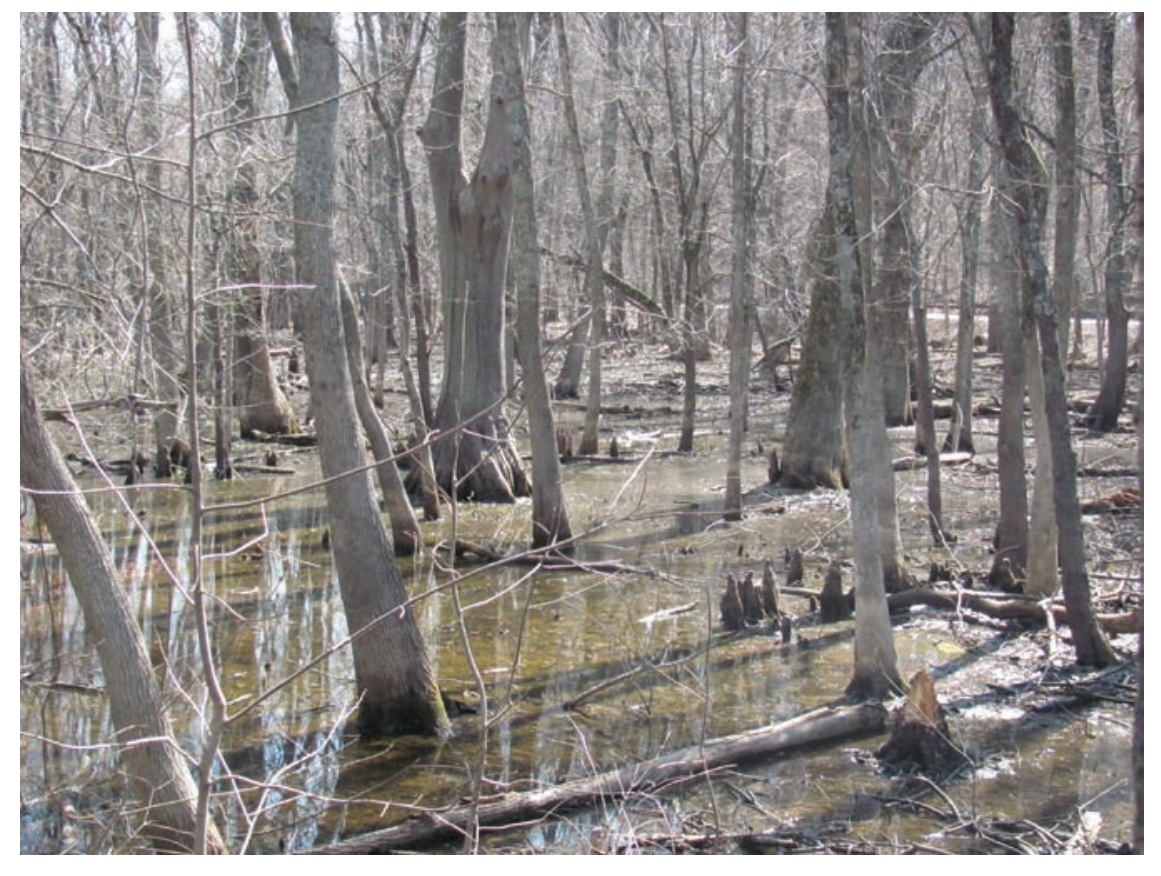

\section{Figure 2}

The five drainage ditches in the southern Little River Drainage District just north and east of the Arkansas border. Map by Mic Greenberg.

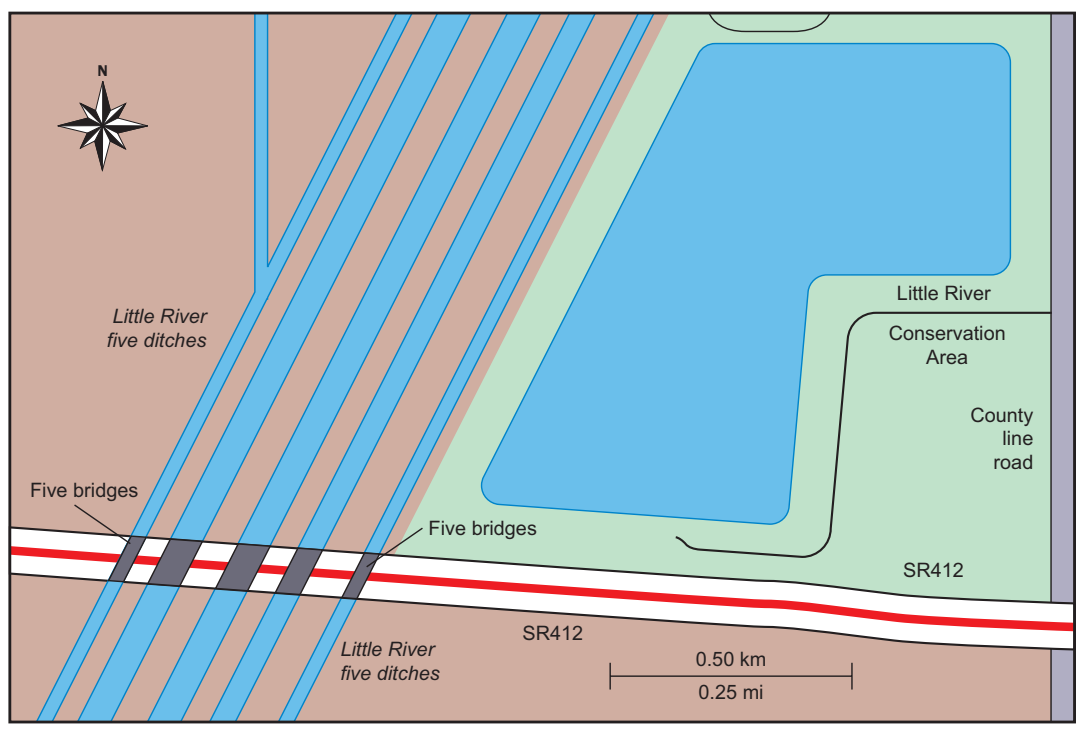

Legend

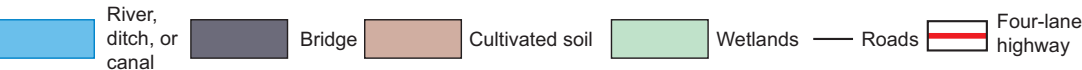


Arkansas. The LRDD is comprised of an west-east headwaters diversion system of 288,000 ha $(720,000 \mathrm{ac})$, which drains the northeast lands directly to the Mississippi River at Cape Girardeau (Olson et al. 2016), and a complex north-south drainage system collecting runoff from 480,000 ha (1.2 million ac) of agricultural and forest lands with $1,540 \mathrm{~km}(957 \mathrm{mi})$ of ditches draining 208,000 ha $(520,000 \mathrm{ac})$ of LRDD bottomlands running south from the diversion channel to the Arkansas border (figure 3).

\section{SWAMPS, SLOUGHS AND FERTILE MISSISSIPPI RIVER VALLEY BOTTOMLANDS}

Historically the path of the Mississippi River just south of Cape Girardeau turned southwest into the current state of Missouri and traveled more than 48 $\mathrm{km}(30 \mathrm{mi})$ to the west before turning south towards Morley, Missouri (Morton and Olson 2013), where it joined with the ancient Ohio River waters draining through the Cache River valley (ancient Ohio River valley) (Olson and Morton

\section{Figure 3}

Little River Drainage District map including the upland that drains into the Headwaters Diversion and the Mississippi River and the upland areas and bottomland area that drain into the St. Francis River. Map by Mic Greenberg.

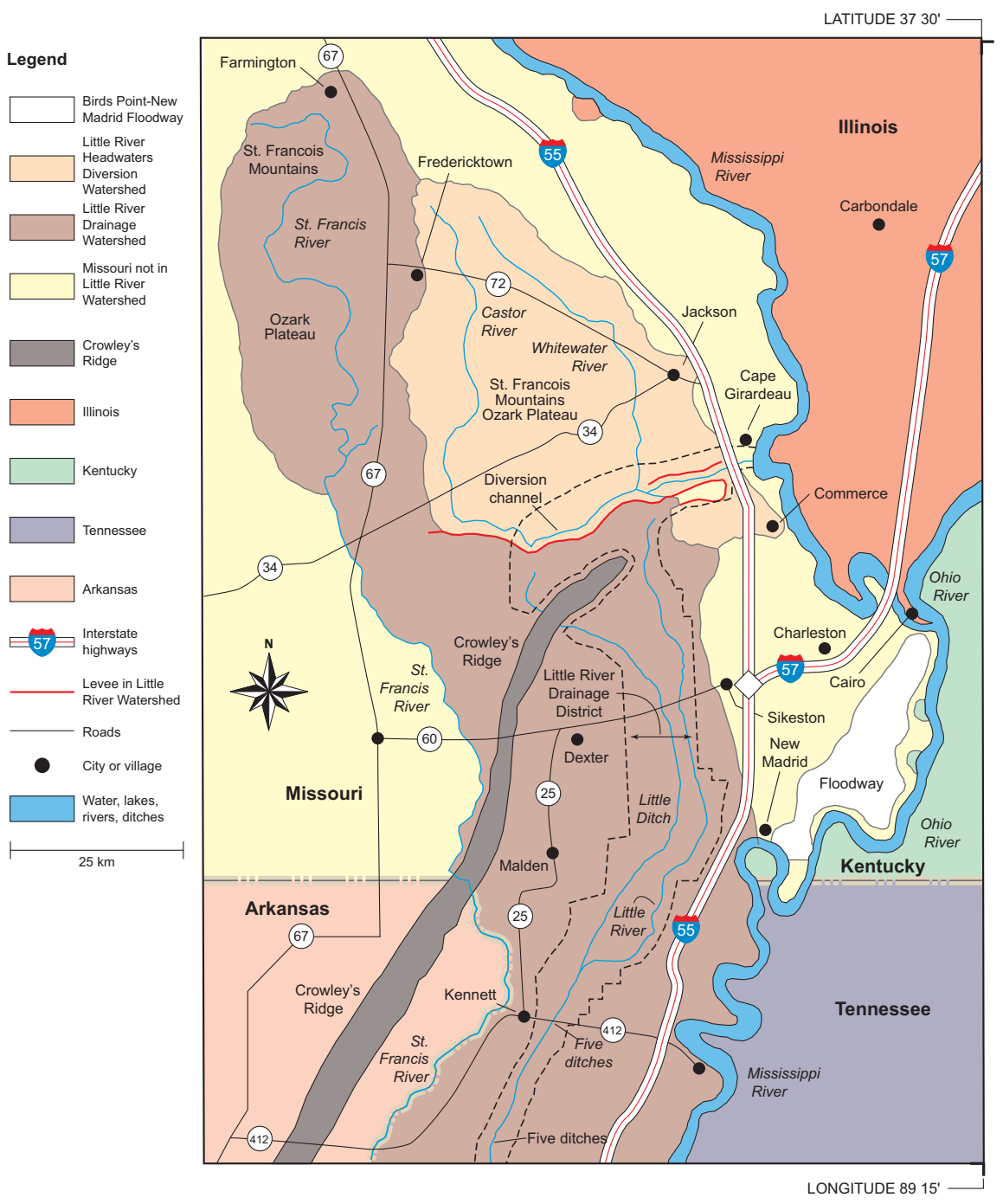

2014a). In the New Madrid area, thousands of years of seismic activity (Vaughn 1994) have affected the Mississippi River channel (Olson and Morton 2014a, 2014b; Olson et al. 2016).

The shifting of the ancient Mississippi River to a new channel left behind an expansive network of perennial streams, swamplands, sloughs, bayous, and fertile riverine bottomlands inundated during much of the year. This Mississippi alluvial valley dissected by Crowley's Ridge produced Big Swamp and bottomlands extending from just below the southern boundary of Cape Girardeau, Missouri, to the Arkansas state line (figure 3), and as far west as the escarpment of the Ozark Plateau. Because of the swampy conditions, less than $15 \%$ of the land was suitable for cultivated agriculture. Plans to turn the 800,000 ha (2 million ac) of swampland into farmland date back to 1840 s, but the task was too big for individual farmers to undertake. Not even the federal government, which owned the swamplands at that time, had ever undertaken a project of that magnitude.

When the European settlers arrived in southeastern Missouri in 1820s, they settled on Crowley's Ridge, which stands 76 to $170 \mathrm{~m}$ (250 to $550 \mathrm{ft}$ ) above the Mississippi River bottomlands (figure 4) and extends $240 \mathrm{~km}(150 \mathrm{mi})$ from southeast Missouri to Helena, Arkansas (Joiner 2008; Stroud and Hanson 1981) (figure 3). Many settlers built homes on top of the semiforested ridge and out of the way of the Mississippi River floods. They used the trees to build homes and make furniture, and as fuel for heat and cooking. The gently sloping ridge had spring fed creeks and soils suitable for cultivation (Memphis silt loam), with the richest soils at the base of the ridge (figure 4). The settlers who farmed the uplands of the ridge found that the loess soils eroded very easily and large gullies formed on some of the slopes of Crowley's Ridge (Blackwell 2007).

\section{NATIONAL SWAMP LAND ACTS}

The National Swamp Land Acts of 1849, 1850, and 1860 transferred public domain swampland considered of no value to states to help them control river flooding and incentivize land development (USGS 


\section{Figure 4}

At the eastern base of Crowley's Ridge are fertile soils, which are irrigated.

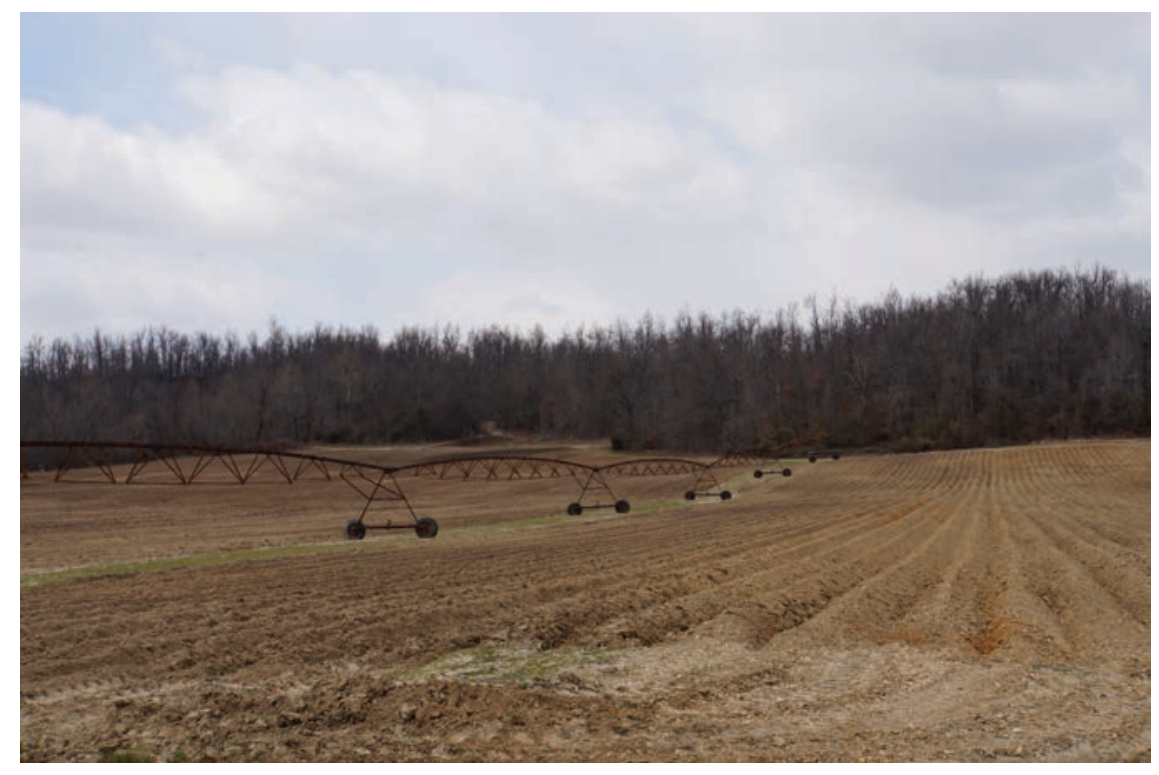

2014). Although the continuously flooding Mississippi River bottomlands were the original target, over a 100 -year period 15 states were authorized to carry out wetland land reclamation programs under this legislation. Swamplands were categorized according to capacity of the land to be made fit for profitable agriculture (USGS 2014). The categories included (1) permanently wet and not fit for cultivation, even in favorable years, unless cleared and levee protected; (2) wet pasture for livestock, with forage often of inferior quality; (3) subject to periodic overflow by streams, but at times able to produce crops; and (4) too wet for profitable crops during abovenormal rainfall, but usable during seasons of light or medium rainfall.

National inventories of wetlands documented over 1.36 million ha (3.4 million ac) of swamp and overflow lands in Missouri as authorized for reclamation. The Swamp Land Act of 1850 gave the swampland southwest of Cape Girardeau to the state of Missouri. From 1860 to 1890 the state conveyed the land to counties. The counties sold the land to private companies and owners. Initially, the bottomlands were not habitable. Before a series of levees were constructed, ordinary runoff and floodwaters regularly spilled across much of southeast Missouri known as the Bootheel, a natural basin which caught the runoff from adjacent uplands and created the Missouri swampland. After the Civil War (1861 to 1865), the opening of the American West by railroads offered greater settlement opportunities in western lands that were more suitable for cultivation than the southeast Missouri swampy bottomlands. However by the 1890 Census, it was clear that the United States no longer had a frontier, and American wetlands became the next area of interest for settlement and cultivation.

In 1875 two Kochtitzky brothers landed in New Madrid, Missouri, to conduct surveys of the region (Kochtitzky 1957). Their father Carl Kochtitzky, a Laclede County clerk in south-central Missouri, learned of the 1850s legislation that granted the swamplands to the state of Missouri and then to the counties. The brothers, in talks with the local county judge, discovered that the old Pole Road, started before the Civil War, was no longer in use, but had charged US $\$ 0.75$ per wagon and US $\$ 0.25$ per bale of cotton (Gossypium hirsutum L.). The Pole Road bed consisted of cut logs laid down side by side to distribute ground pressure for traversing wagons, mules, horses, and people to keep from sinking into the mud. An alternative line for transporting goods and services was the Crowley Ridge road stretching $320 \mathrm{~km}$ (200 mi) from Cape Girardeau to Helena, Arkansas.

Carl Kochtitzky and his sons saw an opportunity to move cotton to market more quickly and formed with four other businessmen the Little River Valley and Arkansas Railroad partnership to install $42 \mathrm{~km}(27 \mathrm{mi})$ of rail from New Madrid to Malden on the Dunkin-New Madrid county line. The winter of 1877 to 1878 was so cold that oxen dragged timbers across ice to the bridge sites. The first year's operation freight volume from cotton only paid the operating costs. To increase the volume of freight, the partners looked at drainage reclamation to create cotton cropland. A new partnership in 1885 contracted to dredge and straighten the Little River from the railroad to the county line. The contract was for US $\$ 0.18 \mathrm{~m}^{-3}$ (US $\$ 0.14 \mathrm{yd}^{-3}$ ) with payment in land valued at US\$3.13 $\mathrm{ha}^{-1}$ (US $\$ 1.25 \mathrm{ac}^{-1}$ ). This brought new land into agriculture and boosted cotton production. Farmers in Pemiscot, Dunkin, New Madrid, and Stoddard counties in 1890 reported to the United States Department of Agriculture (USDA) 16,450 ha (41,491 ac) of cotton, almost double the 9,190 ha $(22,981 \mathrm{ac})$ reported in 1880 (USDA NASS 2014). Another rail venture, started in 1894 and completed in 1899, ran from Cairo, Illinois, to Poplar Bluff, Missouri. The freight for this line was oak staves for wine caskets. During this time, 60,000 ha $(150,000 \mathrm{ac})$ of land became available for reclamation when the title was transferred from New Madrid County in 1899 to the private rail company. The National Swamp Land Act, in concert with railroad construction to connect timber and agricultural interests to new markets, fueled the draining of wetlands for settlement and agricultural expansion.

\section{STUMPS IN THE SWAMPLAND}

The swamps of southeastern Missouri were full of valuable bottomland hardwood trees. These forests were mostly oak (Quercus L.), hickory (Carya Nutt.), and bald cypress trees with some of the oak trees having a circumference as large as $8.2 \mathrm{~m}(27 \mathrm{ft})$ and bald cypress trees with

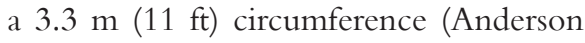
and Samargo 2007). Timber companies 
built drainage ditches, roads, and rail systems to harvest and market this valuable commodity. The 1905 construction of the Thebes railroad bridge between Illinois and Missouri (Olson and Morton 2014b) enabled railroads to build into the Big Swamp (figure 1) and carry the timber to eastern markets. Lumber plants and sawmills like Himmelberger-Harrison in Morehouse, Missouri, provided jobs and made settlement possible. The three largest towns in the Bootheel were New Madrid, Caruthersville, and Charleston, which grew quickly into hubs of trade on the Mississippi River. Their populations peaked in 1890.

By 1910 land purchased by timber and railroad companies was deemed wasteland again, with only tree stumps and water remaining. Lumber companies were left paying taxes on thousands of hectares (acres) of cleared swampland and did not know what to do with it (Blackwell 2007). With broad expanses of the region under 0.9 to $1.2 \mathrm{~m} \mathrm{(3} \mathrm{or} 4 \mathrm{ft}$ ) of water year round and some portions under as much as 4.6 $\mathrm{m}(15 \mathrm{ft})$ near the riverbed, local levee and drainage boards attempted sporadic and uncoordinated efforts to build levees and drainage ditches (Harrison 1961). Lacking engineering skills, financing, and water management experience, these boards made little progress in controlling flooding or reclaiming the swamplands for farming. Although the alluvial soils beneath the water were some of the most fertile soils in Missouri and well suited for farming (Blackwell 2007), these bottomlands seemed impossible to drain.

THE LITTLE RIVER DRAINAGE DISTRICT

Enactment of the Drainage District Law in 1899 was the final legislation enabling comprehensive tax assessments that made it possible to organize drainage districts on a landscape level (Kochtitzky 1957; Olson et al. 2011). This laid the financial infrastructure for a group of visionaries with timber interests and substantial resources to undertake a unified effort to convert the swamp into lands suitable for cultivation. In 1905 a meeting was held in Cape Girardeau, Missouri, to create the LRDD (Olson et al. 2016). The LRDD provided the institutional infrastructure that allowed individual landowners to come together as one to implement and construct a "Plan of Drainage" to meet the federal mandate. The publication of the 1905 Little River drainage map by Otto Kochtitzky helped promote the project and offered a region-wide vision, which inspired investors to purchase bonds and landowners to agree to pay taxes for the land reclamation effort. Formally organized in 1907, the LRDD encompassed 248,000 ha $(620,000 \mathrm{ac})$ in seven Missouri counties (Bollinger, Cape Girardeau, Dunklin, New Madrid, Pemiscot, Scott, and Stoddard) and had a five-person board of supervisors determined to increase the value of the swamplands. The LRDD board of supervisors and their chief engineer developed an engineering plan to drain the entire region. Islam Randolph, an eminent civil engineer from Chicago who had worked on the design and construction of the Chicago Sanitary and Ship Canal and the Panama Canal, was employed as a consulting engineer and approved the drainage plan (personal communication from LRDD Chief Engineer Larry Dowdy, August 5, 2015; LRDD 1909). The new drainage and levee system opened the land for settlement, agriculture, and industrial land uses and became one of the largest human transformations of a landscape in world history.

Three important developments paved the way for the LRDD project success: (1) Missouri transferred ownership of swamplands to counties, and counties sold the land to entrepreneurs; (2) entrepreneurs built railroads in and out of swamps; and (3) large-scale lumbering operations cleared the thick forested bottomlands. Once the timberland was cleared, the timber companies could sell land for a profit to those with agricultural interests. Drainage enabled the land use conversion. Thousands of workers participated in the difficult and dangerous work of clearing, mostly by hand, the swamp of trees and stumps. The workers and their families came from many states, including the adjacent states of Kentucky and Illinois. Houseboats were home for many of the men and women who dug drainage channels and built the levees; others lived in tents in temporary settlements.
The LRDD drained the swampland between 1909 and 1928 by digging a 72 $\mathrm{km}(45 \mathrm{mi})$ channel that diverted water from the Ozark Plateau and Francois Mountains (figure 3) away from the bottomlands and into the Mississippi River at Cape Girardeau. With the west-east Headwaters Diversion in place, the LRDD could take advantage of the $0.2 \mathrm{~m} \mathrm{~km}^{-1}$ (1 $\mathrm{ft}^{-1} \mathrm{i}^{-1}$ ) drop from Cape Girardeau to the Arkansas border and construct a northsouth gravity system of levees and ditches. In 1914 the lower drainage district work resulted in a series of ditches totaling nearly $1,500 \mathrm{~km}$ (957 mi). The largest ditch, 155 $\mathrm{km}$ (100 mi) long Ditch 1, collected the runoff from all other ditches in the district and carried it south into Arkansas where it entered though the St. Francis River and later ran into the Mississippi River, a distance of $390 \mathrm{~km}$ (250 mi). By 1928, the district had completed construction of the levees and ditches and had drained 208,000 ha $(520,000 \mathrm{ac})$ of bottomland. The diversion canal transported runoff water from 288,000 ha $(720,000 \mathrm{ac})$ of uplands (Francois Mountains and Ozark Plateau) to the Mississippi River. Two detention reservoirs and one sedimentation basin were created to catch sediment and runoff from other creeks. The area not covered by water increased from $10 \%$, mostly the upland hills remaining in the former Mississippi Valley bottomlands (figure 3), to $96 \%$.

The drainage districts of Arkansas were unprepared to manage the full brunt of the LRDD plan to discharge their runoff into Big Lake, Arkansas, just south of the Missouri border. In 1917, the Mingo Drainage District and Inter-River Improvement District were created in Missouri and provided the final provocation for the inhabitants of eastern Arkansas who were to receive the drainage waters. According to engineers' calculations, the planned improvements would increase the flow of the St. Francis River into Arkansas during flood events 5 to 10 times its previous volume. If the plans were completed, Arkansas newspaper articles promised nothing short of "ruination for the people of the St. Francis River valley" (Harrison 1961). Further it was claimed that the improvements would drive the people 
of Arkansas out of their homes and away from their farms and factories. Nothing posed a more serious threat to the people of Arkansas than these two Missouri drainage districts (Harrison 1961). Senator Thaddeus H. Caraway joined the fray, and in a letter to the "prominent men in Eastern Arkansas," he warned that the Missouri-intended diversion of the overflow from the Ozarks would turn the entire water column loose on Arkansas. Senator Caraway counseled Arkansans to seek an injunction against the Missouri improvement districts until the US government canalized or dredged the St. Francis River (figure 3) to control the increased volume of water (Harrison 1961). The Little River flow estimates did not appear to be adjusted to reflect the 288,000 ha $(720,000 \mathrm{ac})$ of Francois Mountain and Ozark Plateau runoff that was diverted in 1915 to the Mississippi River south of Cape Girardeau by the LRDD Headwaters Diversion.

With local and state protests growing, Congress finally responded to the increased need for a consistent flood control policy across states. The RansdellHumphreys Flood Control Act of 1917 reaffirmed the federal government's commitment to flood prevention and control but only appropriated US $\$ 45$ million, which was insufficient to address the problem. However, local and state interests were encouraged by a provision of the act that reduced their contribution to half the cost of flood prevention works in their area from the previous two-thirds local match required. In the same year, the Arkansas General Assembly authorized the establishment of six drainage districts by direct legislation. These districts established a series of ambitious, interrelated projects designed to reclaim their lands by drainage ditches and levees. As part of the improvements, the Arkansas and Missouri drainage districts straightened and deepened a shallow, sluggish creek to handle the increased flow. The improved channel was renamed Ditch 4. Drainage districts' plans in both Arkansas and Missouri were revised between 1917 and 1926 as construction continued. Following the great flood of 1927, the plans had to be revised again, but draining and land development continued. Flood control legislation in 1928 authorized the USACE to work in the St. Francis River Basin and to assist the LRDD in improving and maintaining the Headwaters Diversion channel and levee and the lower north-south channels that collected district water for discharge into Big Lake Wildlife Refuge in northern Arkansas (Harrison 1961). Today, through a collection system in Arkansas not operated by the LRDD, the water flows into the Mississippi River at Helena, Arkansas.

\section{SWAMPLAND TO AGRICULTURE}

By 1930 much of the former Mississippi River valley southwest of Cape Girardeau, Missouri, was settled, and the newly drained alluvial bottomland soils were drained and converted to farming (figure 5). Over time, many hectares (acres) of publicly owned swampland were transferred to private owners who invested in drainage and land development, consolidating the LRDD into fewer and larger parcels. In 2007 about 3,000 landowners had holdings ranging from $0.2 \mathrm{ha}(0.5 \mathrm{ac})$ to 20,000 ha (50,000 ac) (Blackwell 2007).

The increase in acreage available for agricultural production since drainage efforts were undertaken has been dramatic. Cotton, corn (Zea mays L.), and wheat (Triticum aestivum L.) were the primary crops of southeast Missouri in 1880, with a total of 9,322 ha $(23,304 \mathrm{ac}), 49,115 \mathrm{ha}$ $(122,788 \mathrm{ac})$, and 14,209 ha $(35,523 \mathrm{ac})$, respectively, reported for seven counties (figure 6; Pemiscot, Dunkin, New Madrid, Stoddard, Scott, Cape Girardeau, and Bollinger counties) (USDA NASS 2014). The 1890 Census of Agriculture (USDA NASS 2014) shows an increase in total hectares (acres) of these three crops from 72,646 ha $(181,615 \mathrm{ac})$ in 1880 to 158,992 ha $(397,480 \mathrm{ac})$ in 2012 , a more than $200 \%$ increase. Much of this increase can be attributed to a combination of the Swamp Land Acts, increased settlement, and local drainage districts' efforts. Following the completion of the LRDD drainage system and post-Depression years, almost 311,200 ha $(778,000 \mathrm{ac})$ were reported in 1940 for corn $(136,257$ ha $[340,643 \mathrm{ac}])$, cotton $(100,066$ ha $[250,164 \mathrm{ac}])$, wheat $(40,920$ ha [102,300 ac]), and soybean (Glycine max [L.] Merr.; 33,940 ha [84,849 ac]), a 196\% increase from 1890. By 1974 soybean acres topped 460,000 ha $(1.15$ million ac) in the seven counties, and wheat was reported on 140,588 ha $(351,469 \mathrm{ac})$, cotton on 113,206 ha $(283,015 \mathrm{ac})$, and corn on 37,744 ha $(94,361 \mathrm{ac})$. The addition of soybean to the cropping mix enabled farmers to double crop with wheat and take full advantage of the continental cli-

\section{Figure 5}

Agricultural lands created by draining the Big Swamp.

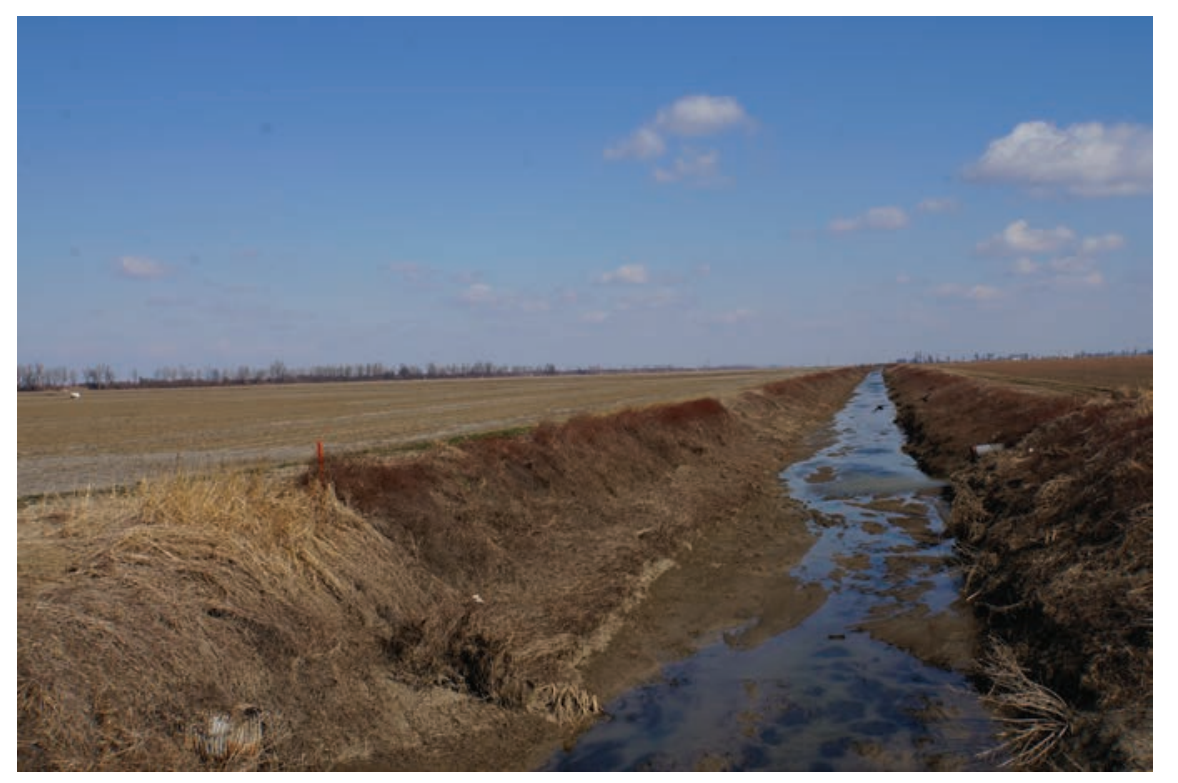




\section{Figure 6}

Extent of crops commonly grown in the seven southeastern counties located in the Little River Basin watershed from 1880 to 2012. Note that dates shown are not in even increments.

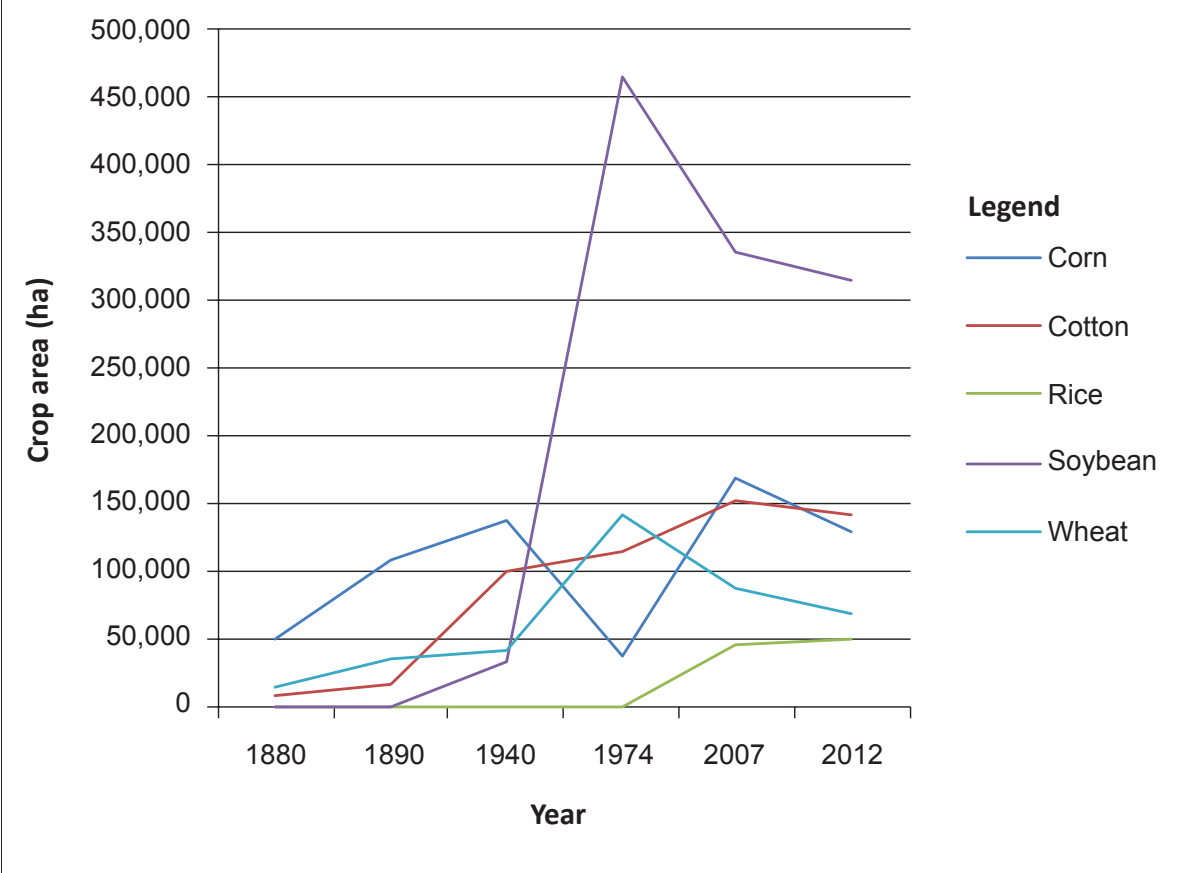

mate and soils that were no longer under water during the long growing season. Rice (Oryza sativa L.) hectares (acres), which were only recorded in Stoddard County in 1974, expanded throughout the region with a total of 46,147 ha $(114,034$ ac) and 49,305 ha $(121,836 \mathrm{ac})$ reported in the lower five counties (Pemiscot, Dunkin, New Madrid, Stoddard, and Scott) in 2007 and 2012, respectively. Since 1974, these five commodity crops totaled 680,000 ha (1.7 million ac) in 2012 with a record high of 760,000 ha (1.9 million ac) in 2007. Today, in addition to these commodities, the LRDD-drained farmlands produce sorghum (Sorghum bicolor [L.] Moench), vegetables, peaches (Prunus persica [L.] Batsch), watermelons (Citrullus lanatus), and other fruits. Missouri's top wheat, soybean, and sorghum producing counties are all found in this region and report some of the highest corn, wheat, and sorghum yields in the state.

\section{LITTLE RIVER DRAINAGE DISTRICT LEGACIES AND FUTURE CHALLENGES}

Without the unified investment of the LRDD, the main interstate north-south highway, I-55 (figure 3), would have have also declined since the surge when land was first drained and cleared.

The US Geological Survey (2014) estimates that almost all of the 26 million ha (65 million ac) of wetlands given to the states under the Swamp Acts are now in private ownership. In 1900, the swamplands of the Mississippi River alluvial plains were considered wasteland of little to no value, obstacles to settlement and the development of commerce. Soils' capacity to grow row crops has been the historical metric used to determine whether land is valuable or marginal (Hatfield and Morton 2013). The agricultural productivity of this region is testimony to the effectiveness of the LRDD elaborate system of ditches, retention basins, and levee-protected lands. Only in recent years have scientists understood the multifunctional uses and ecosystem services that saturated soils and wetlands provide and what is lost when they are converted to other land uses. Not only does agricultural drainage alter hydrologic patterns, but it also alters the biodiversity of habitat and reduces water quality when soil erodes and farm nutrients run into the ditches (Blann et al. 2009).

The LRDD intricate system of drainage ditches moves more than 117.3 million L (31.5 million gal) of water annually off the land and into the Mississippi River. The drainage district's investments in the Headwaters Diversion channel, levees, and ditches, along with the construction of the Thebes railroad bridge (Olson and Morton 2014b), created an economic and technological engine that resulted in the successful conversion of the Big Swamp to productive agricultural lands during the past 111 years. Had the conversion been delayed for 100 years, the area would probably have become a federally protected wetland preserve (Blackwell 2007). Advances in agriculture and water management have helped engineers better understand how to manage artificially drained low-gradient agricultural lands. However, the tension between wetland services and agricultural land uses will continue to increase and be a future challenge that the LRDD will need to address in order to find some level of balance among competing economic, social, and biophysical conditions. 
The LRDD oversight of so many thousands of hectares (acres) well positions it to evaluate and address the landscape-wide vulnerability of drained and levee-protected lands from interior and river flooding as precipitation and extreme and variable weather stress their infrastructure and affect downstream communities. Without continual maintenance and repair of ditches and levees, these Mississippi River bottomlands have a predisposition to flood farmland seasonally and revert back to the wetlands of the past. Further, the straightening of streams and channelization of water to move water off fields is a source of soil erosion and bank scouring that needs constant attention to control sedimentation throughout the system. One of the big challenges that Mississippi River drainage districts and the USACE face is how to best manage the water velocity and emergent vegetation in their drainage systems to control seasonal flooding, keep the channel beds stable, and reduce off-field and landscape-wide nutrient losses while creating habitat diversity under seasonal drought and uncertain climate patterns (Pierce et al. 2012).

The 2007 LRDD report (LRDD 2007) celebrating their 100-year anniversary well summarizes the changes that have occurred and the challenges that continue into the future:

This region was once a bog, a swamp, a lowland, a morass, a hunting and fishing paradise, a no man's land, an endless stretch of virgin hardwood timber, a moss, a stillness that stole the sleep from the tired, a hideout, a barrier, a challenge to do the impossible. Today a traveler driving across the areas could never know of these things as he or she passes field after field laid out on a perfect grid, interrupted only occasionally by a narrow bridge every mile or so. Below them, however, the swamp does not sleep and labors to regain itself, held only at bay by the never-ending work of men and women of the Little River Drainage District.

\section{ACKNOWLEDGEMENTS}

Partial funding for this research was provided by the Iowa Agriculture and Home Economics Experiment Station, College of Agriculture and Life Sciences at Iowa State University and the multistate project, NC1190 Catalysts for Water Resources Protection and Restoration. Funding support also comes from Regional Research Project No. 15-372 and in cooperation with North-Central Regional Project No. NCERA-3 Soil Survey; and from the Director of the Illinois Office of Research, College of Agricultural, Consumer, and Environmental Sciences, University of Illinois, Urbana, Illinois. The National Great Rivers Research and Education Center provided funds to make this article open access.

\section{REFERENCES}

Anderson, J., and E. Samargo. 2007. Bottomland Hardwoods. Morgantown, WV: West Virginia University, Division of Forestry and Natural Resources. http://forestandrange.org/new_wetlands/index.htm.

Blackwell, S. 2007. A landscape transformation by the Little River Drainage District. Southeast Missourian. Nov. 4, 2007.

Blann, K.L., J.L. Anderson, G.R. Sands, and B Vondracek. Effects of agricultural drainage on aquatic ecosystems: A review. Critical Reviews in Environmental Science and Technology 39:909-1001.

Camillo, C.A. 2012. Divine Providence: The 2011 Flood in Mississippi River and Tributaries Project. Vicksburg, MS: Mississippi River Commission.

Gellman, E.S., and J. Roll. 2011. The Gospel of the Working Class. Urbana-Champaign, IL: University of Illinois Press.

Harrison, R.W. 1961.A study of state and local efforts toward land development in the Alluvial valley of the lower Mississippi River. In Alluvial Empire. USDA Economic Research Service.

Hatfield, J.L., and L.W. Morton. 2013 Marginality principle. In Advances in Soil Science, eds. R Lal and BA Stewart. New York: CRC Press.

Joiner, J. 2008. Little River drainage district work was completed in 1928. Rural Missouri, Association of Missouri Electric Cooperatives Report.

Kochtitzky, O. 1957. Memoir, 1931. In The Story of a Busy Life. Cape Girardeau, MO: Ramfre Press.

LRDD (Little River Drainage District). 1909. Final report of Board of Engineers of Little River Drainage District of Missouri [Exhibit III]. Cape Girardeau, MO: Little River Drainage District.

LRDD. 2007. Little River Drainage District (LRDD) of southeast Missouri 100 year report 1907-2007. Cape Girardeau, MO: Little River Drainage District.

Morton, L.W., and K.R. Olson. 2013. Birds Point-New Madrid Floodway: Redesign, reconstruction and restoration. Journal of Soil and Water Conservation 68(2):35A-40A, doi:10.2489/jswc.68.2.35A.
Olson, K.R., and L.W. Morton. 2014a. The 2011 Ohio River flooding of the Cache River Valley in Southern Illinois. Journal of Soil and Water Conservation 69(1):5A-10, doi:10.2489/ jswc.69.1.5A.

Olson, K.R., and L.W. Morton. 2014b. Dredging of the fracture bedrock lined Mississippi River channel at Thebes, Illinois. Journal of Soil Water Conservation 69(2):31A-36A, doi:10.2489/ jswc.69.2.31A.

Olson, K.R., L.W. Morton, and D. Speidel. 2016. Missouri Ozark Plateau Headwaters Diversion engineering feat. Journal of Soil and Water Conservation 71(1):13A-19A, doi:10.2489/ jswc.71.1.13A.

Olson, K.R., M. Reed, and L.W. Morton. 2011. Multifunctional Mississippi River leveed bottomlands and settling basins: Sny Island Levee Drainage District, Journal of Soil and Water Conservation 66(4):104A-110A, doi:10.2489/ jswc.66.4.104A.

Pierce, S.C., R Kroger, and R. Pezeshki. 2012. Managing artificially drained low-gradient agricultural headwaters for enhanced ecosystem functions. Biology 1:794-856, doi: 10:3390/ biology1030794.

Pracht, C., and J. Banks. 2002. The Little River Drainage District collection. Collection Building 21(1):10-12.

Stroud, H.B., and G.T. Hanson. 1981. Arkansas geography: The physical landscape and geography. The Encyclopedia of Arkansas History and Culture. Historical-cultural Setting. Little Rock: Rose Publishing.

USDA NASS (National Agricultural Statistics Service). 2014. USDA Census of Agriculture. Washington, DC: USDA National Agricultural Statistics Service.

USGS (US Geological Survey). 2014. Wetlands of the United States. http://www.nwrc.usgs.gov/ topics/wetlands/wetlandResources.htm.

Vaughn, J.D. 1994. Paleoseismological studies in the Western Lowlands of southeastern Missouri. Final Technical Report to US Geological Survey 1-27. 